\title{
Diversity Threats and Incidents of Violence over the Staff, Ministry of Health
}

\section{Mohammad Fairuszaman Rustam, Nurul Fadly Habidin}

To Link this Article: http://dx.doi.org/10.6007/IJARBSS/v11-i1/9008

DOI:10.6007/IJARBSS/v11-i1/9008

Received: 06 December 2020, Revised: 03 January 2021, Accepted: 12 January 2021

Published Online: 29 January 2021

In-Text Citation: (Rustam \& Habidin, 2021)

To Cite this Article: Rustam, M. F., \& Habidin, N. F. (2021). Diversity Threats and Incidents of Violence over the Staff, Ministry of Health. International Journal of Academic Research in Business and Social Sciences, 11(1), 858-866.

\section{Copyright: @ 2021 The Author(s)}

Published by Human Resource Management Academic Research Society (www.hrmars.com)

This article is published under the Creative Commons Attribution (CC BY 4.0) license. Anyone may reproduce, distribute, translate and create derivative works of this article (for both commercial and non-commercial purposes), subject to full attribution to the original publication and authors. The full terms of this license may be seen at: http://creativecommons.org/licences/by/4.0/legalcode

Vol. 11, No. 1, 2021, Pg. 858 - 866

Full Terms \& Conditions of access and use can be found at http://hrmars.com/index.php/pages/detail/publication-ethics 


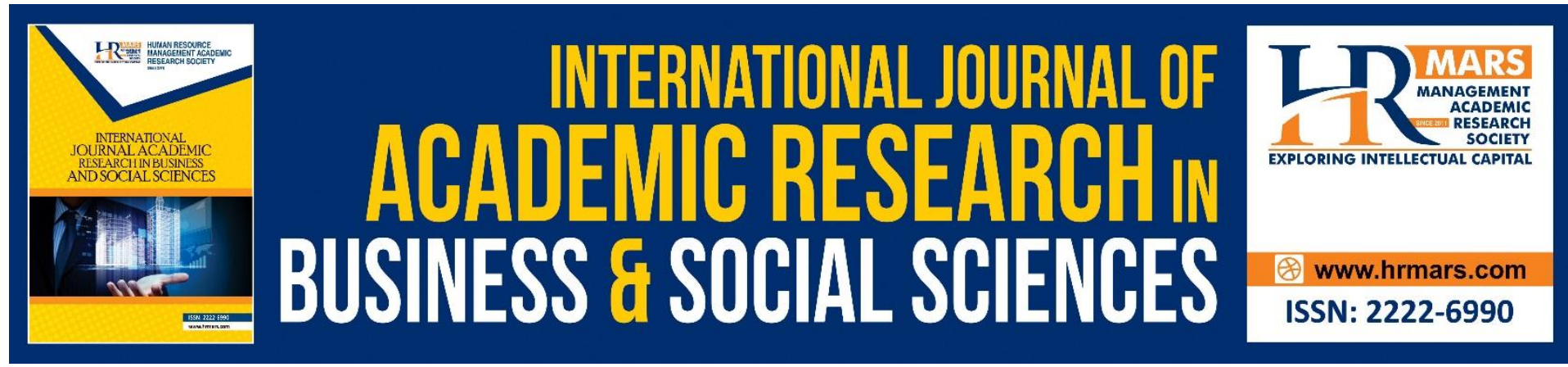

\title{
Diversity Threats and Incidents of Violence over the Staff, Ministry of Health
}

\author{
Mohammad Fairuszaman Rustam, Nurul Fadly Habidin \\ Faculty of Management and Economics, Sultan Idris Education University 35900 Tanjung \\ Malim, Perak, Malaysia
}

\begin{abstract}
In recent times, the threats and incidents of violence perpetrated by civilians have become more and more prevalent and frequent among members and health workers. The problem occurs in most health facilities, especially in government hospitals and health clinics. It is clear that threats and violence that indirectly interfere with the productivity of staff and employees in the Ministry of Health, Malaysia (MOH). As such, these threats and incidents of violence also affect and impact the sustainability of the delivery of medical services especially to the people of the country. On the other hand, it is also a concern that it may affect the ability of the organization to function well and maintain a strong corporate image. Examples of the diversity of threats and incidents of violent violence are frequently encountered by $\mathrm{MOH}$ health workers such as physical attacks, verbal attacks, social media outbreaks and so on. However, most cases of these threats and violence are often not reported. Unfortunately, the threats and incidents of violence come from patients and families of patients. It is a challenge that needs to be addressed more professionally to ensure uninterrupted service continuity and continuous service delivery to customers
\end{abstract}

Keywords: Threats, Violence, Hospital, Clinic, Ministry of Health Malaysia (MOH)

\section{Introduction}

In pursuing a modernization that is based on science and information technology, personnel under the Ministry of Health $(\mathrm{MOH})$, particularly in hospitals and government clinics, often confronted with threats and violence conflicts of either physical, verbal, sexual or sexual harassment and incidents of information dissemination on social media. Today's borderless communication facilities, allows the sharing of information and the spread of rumors happen more quickly. However, concerns over whether the information and news presented and disseminated have been supplemented or forged. This has resulted in the productivity of $\mathrm{MOH}$ employees being often disturbed and affected in their professional duties.

In the context of the discussion, Zainal et al (2018), defined the meaning of the word violence as, any kind of customer behavior towards $\mathrm{MOH}$ members involving physical, verbal, sexual or written attacks with the intent to injure, create damage or cause psychological harm to the victim. According to Arnetz et al., (2015), the Occupational Safety and Health Administration (OSHA) reports that approximately 75 percent of the 25,000 workplace assault cases reported 
each year occur in the health and care services environment. According to them, workers in the healthcare and healthcare environment are four times more likely to be victimized than workers in other private industries. Vellani (2014), mentioned that, a review of national crime victims shows that healthcare workers have a 20 percent higher likelihood of being victimized in the workplace compared to workers from other occupations.

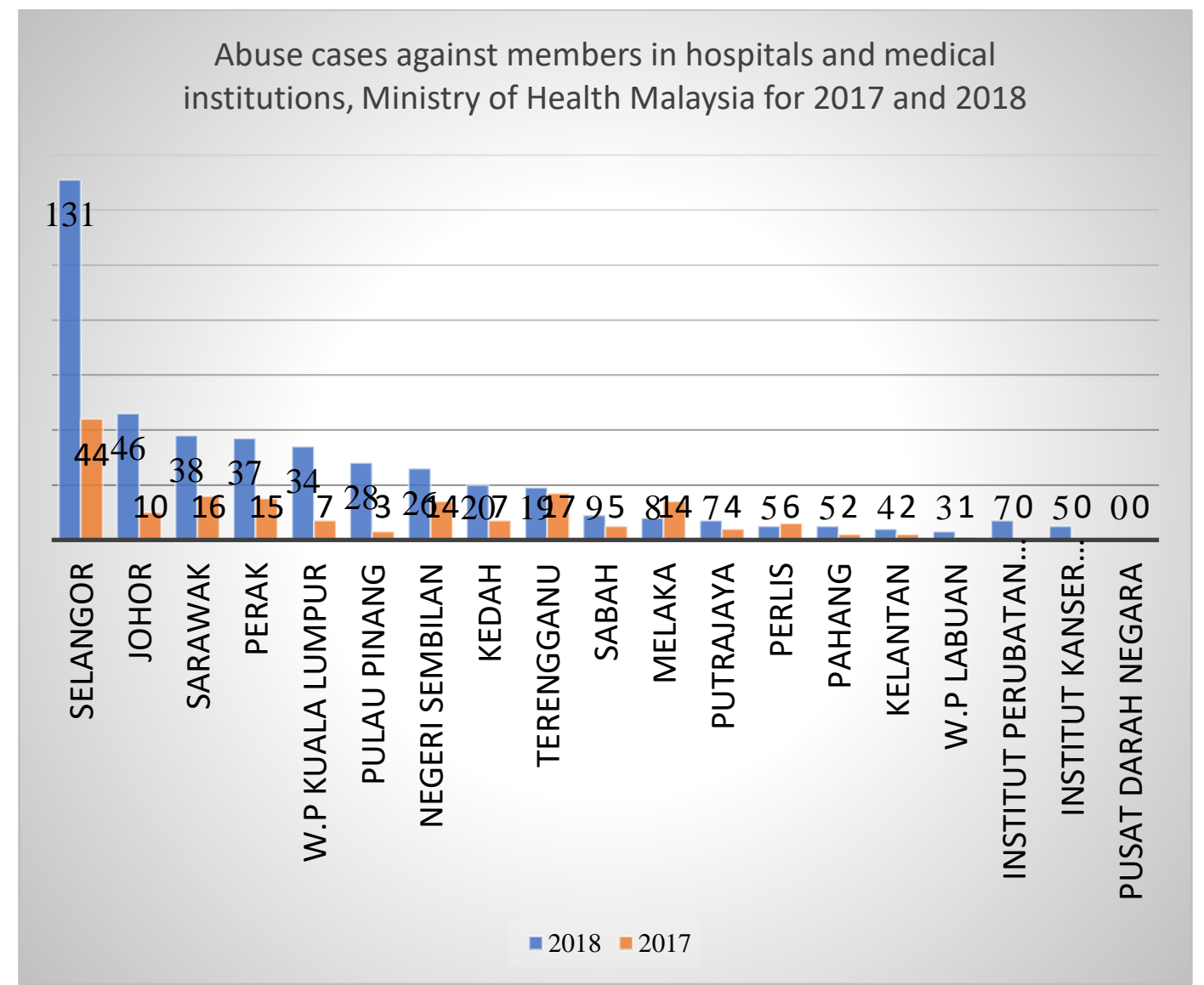

Chart 1: Number of Violent Cases on Hospitals and Medical Institutions, Ministry of Health Malaysia, For 2017 and 2018 (MOH Annual Report, 2018)

\section{Health Facility Ministry of Health Malaysia (MOH)}

Generally, various budgetary touches affecting all levels of society, agencies and departments are often presented in the House of Representatives. Through the text of the newly announced Budget 2020; Malaysian Finance Minister Lim Guang Eng announced the government's plan to provide an allocation of RM30.6 billion to ensure the people of the country have access to quality healthcare for all, in line with the aspirations of an inclusive society. In this context, the overall health achieved is one of the key indicators of national success. Good health enables Malaysians to enjoy a more productive and meaningful life. However, in delivering the service, challenges often occur. Issues such as incidents of violence against employees of the Ministry of Health Malaysia have become one of the most pressing issues and challenges.

Further to the above mentioned, the latest information on the number of facilities under the Ministry of Health Malaysia (MOH) is recorded. Statistics released by $\mathrm{MOH}$ in 2019 show that as many as 135 Government hospitals have been built and operate to date. The number of Special Medical Institutions is 9 and the number of Health Clinics is 1000 . Subsequently, there 
were a total of 1791 Village Clinics and 90 Maternal and Child Health Clinics. The 1 Malaysia Clinic (K1M) has been developed in selected urban areas since 2010. Its objective is that K1M provides basic medical services for a variety of minor health and injury problems that are often encountered by the community. Among the forms of treatment and care he offers include fever, cough, colds, high blood pressure, diabetes and minor injuries. As of December 31,2018 , a total of $343 \mathrm{~K} 1 \mathrm{Ms}$ nationwide have been operating and providing and offering basic care services. From the above it is clear that the strengthening of health facilities services throughout the country contributes to the overall prosperity and social stability of the people in this country.

Table 1: Health facilities by type, hospital and medical institution, Ministry of Health Malaysia, for 2017 and 2018

\begin{tabular}{|c|c|c|c|c|c|c|}
\hline Total number of facilities & 2013 & 2014 & 2015 & 2016 & 2017 & 2018 \\
\hline Hospital & 132 & 133 & 134 & 135 & 135 & 135 \\
\hline Special Medical Institution & 9 & 9 & 9 & 9 & 9 & 9 \\
\hline Health clinic & 934 & 956 & 958 & 969 & 994 & 1000 \\
\hline Clinic & 1821 & 1810 & 1808 & 1803 & 1798 & 1791 \\
\hline Maternal and Child Health Clinic & 105 & 105 & 103 & 91 & 91 & 90 \\
\hline Clinic 1 Malaysia & 254 & 307 & 334 & 357 & 342 & 343 \\
\hline
\end{tabular}

\section{Violence against members of $\mathrm{MOH}$ facilities}

As stated by Zainal et al (2018), rudeness or violence can be defined by various definitions or meanings. According to a statement from the World Health Organization (WHO), rudeness or violence meant to intentionally using physical force or violence, threats or acts of violence against a group or community, that causes is likely to injury, death and psychological effects.

According to Bride et al (2015), a study by most countries has shown that workplace violence has become one of the endemic problems for those working in the healthcare sector. As mentioned by Speroni et al., (2014), estimated to be one-quarter of workplace violence worldwide, occurs in developed and developing countries in the sector. According to a retrospective survey conducted by the Occupational Safety and Health Unit, the Medical Development Division involving 11 state-run hospitals in Malaysia. A total of 44 cases of violence were reported during the period 2013 to 2016. Subsequently, more systematic and comprehensive data collection monitoring was initiated. The results of the surveys revealed that 167 cases have been reported. These data were obtained after the Guidelines for Preventing and Addressing Violence against Members at the $\mathrm{MOH}$ Facility were launched in 2017. In addition, a total of 432 cases from January to December 2018 were also recorded.

Table 2: Number of cases of violence against members in hospitals and medical institutions, Ministry of Health Malaysia, for 2017 and 2018

Statistics of violence against members in $\mathrm{MOH}$ hospitals and medical institutions

Violence against members at $\mathrm{MOH}$

hospitals and medical institutions was

reported
2013 to 2016

2017

2018

44 case

167 case 


\section{Types of Violence against Members in $\mathrm{MOH}$ Hospitals and Medical Institutions}

According to Speroni et al., (2014), the World Health Organization has categorized workplace violence into two types: (1) physical violence, for example, hitting, kicking, slapping, stabbing, shooting, pushing, biting, and pinching; and (2) psychological violence of physical violence against another person or group that may pose a danger to physical, mental, spiritual, moral, or social development. Liu et al., (2015) said that workplace violence in the healthcare sector has become part of the worldwide concern. Workers in the healthcare sector are constantly exposed to higher risks and challenges.
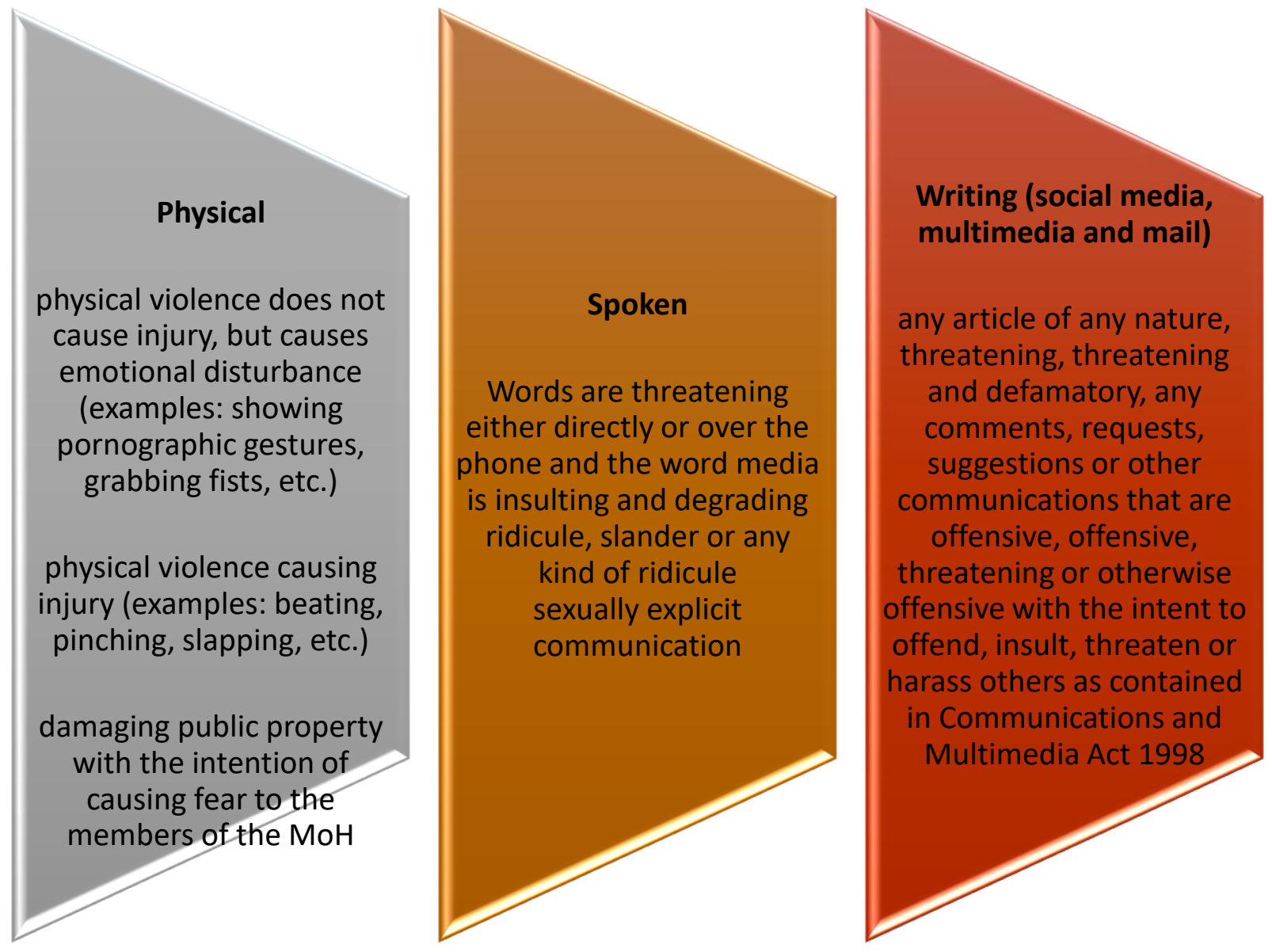

Figure 1: The definition of violence Ministry of Health

Statistics on reporting and handling of cases of violence against members of the Ministry of Health for 2018 have shown an increase of 432 cases compared to the previous year which recorded only 167 cases. In the years 2013 to 2016, 44 cases were reported and recorded. On closer scrutiny, more systematic and comprehensive cases of violence cases have been initiated following the launch of the Guidelines for Preventing \& Addressing Violence against Members at the Ministry of Health Malaysia's Facility held in April, 2017. An analysis of reporting of cases of violence and violence In 2018, 299 cases (48\%) were reported verbally. It was followed by reports of 141 cases of physical violence (23\%), bullying or intimidation of 107 cases (17\%), written (letter, social media, sms) of 31 cases (5\%), vandalism of 22 cases (4\%) ) and sexual 18 cases (3\%). The analysis also revealed that in 2018 Trained Nurses topped the list of 28 victims (121 cases), followed by Medical Officers 23 percent (101 cases) and Assistant Medical Officers 10 percent (45 cases). As per the data collected and recorded in 
the Occupational Safety and Health Unit report, the Medical Development Division, for 2017 and 2018, the state with the highest number of abusive cases for both years was in the state of Selangor. Most of the cases reported occurred in government medical facilities of 131 hospitals in 2018 and 44 cases in 2017.

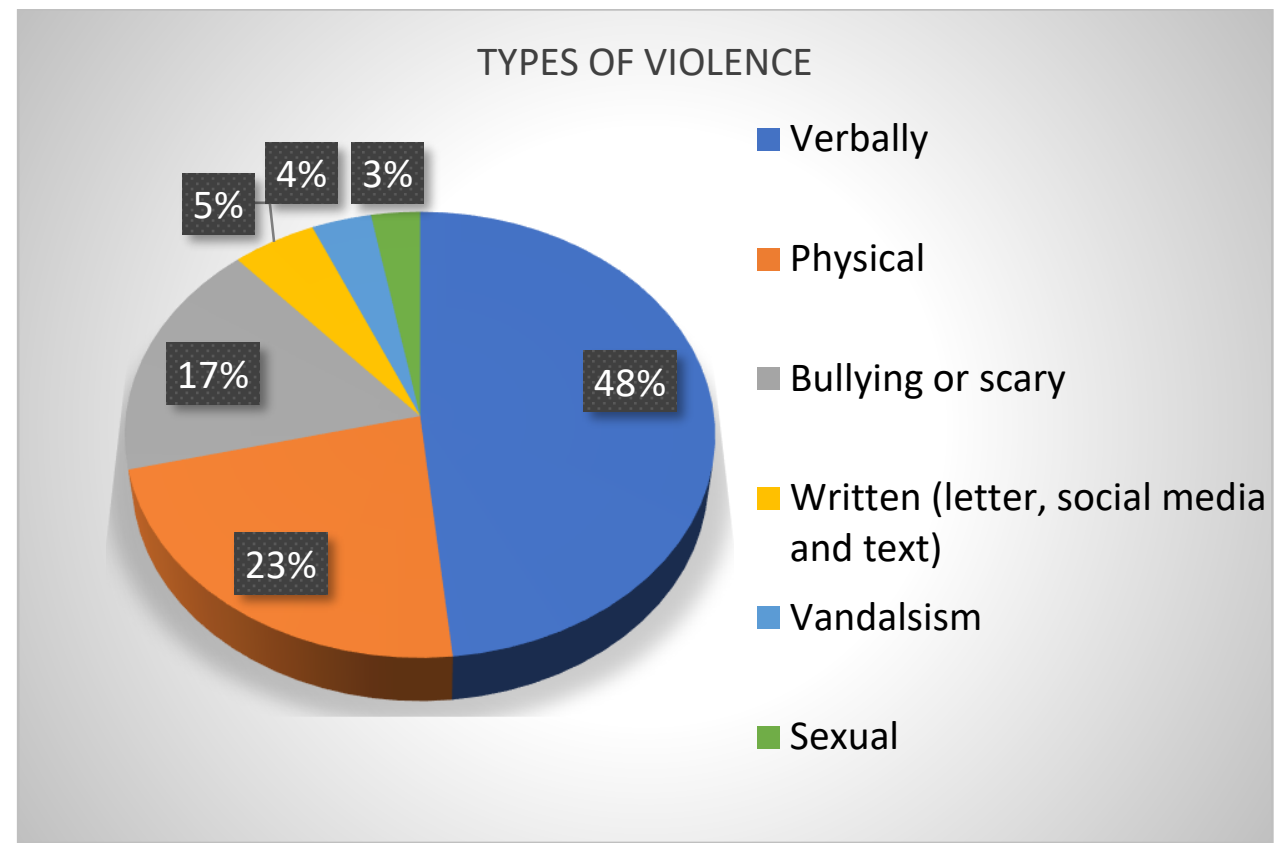

Chart 2: Types of cases of violence against staff in hospitals and medical institutions, Ministry of Health Malaysia, for 2017 and 2018

\section{Causes and Factors of Violence}

According to Saperoni et al., (2014), the issue of violence is not a new issue in civilization and human civilization. In the context of today's world, the leading cause of violence is the result of dissatisfaction and is a form of protest. Philips, (2016) said that health facilities such as hospitals and care centers are at high risk for a wide range of incidents involving incidents of violence and intrusion. Therefore, it is important to ensure that forms of incidents and violence are reviewed and reviewed so that preventive measures can be taken to prevent such incidents from occurring (Warren, 2011).

According to Gates et al., (2011), every incident of workplace violence needs to be researched to determine the contributing factors to the occurrence of violence. Information relating to workplace violence, and the circumstances of the workplace, need to be analyzed to determine the actual situation and the underlying causes of violence. In addition, the analysis and evaluation undertaken is intended to determine trends and hotspots, to identify and determine where, when, why and how incidents of violence occur and to whom violence often takes place. As mentioned by Vellani, (2014), this process can contribute to measures that can be taken and implemented to reduce the likelihood of incidents of violence. Causes and factors of violence towards $\mathrm{MOH}$ members include the attitude of the perpetrator, which generally consists of patients, beneficiaries and visitors. In addition, a review of the data obtained by the Ministry of Health Malaysia also found that patient health factors, communication problems, long wait times, attitude among $\mathrm{MOH}$ members, non-compliance with standard operating procedure or SOP, patients under the influence of drugs or alcohol 
and the environment is also the cause of the occurrence of a case of marketing at a health facility under the $\mathrm{MOH}$.

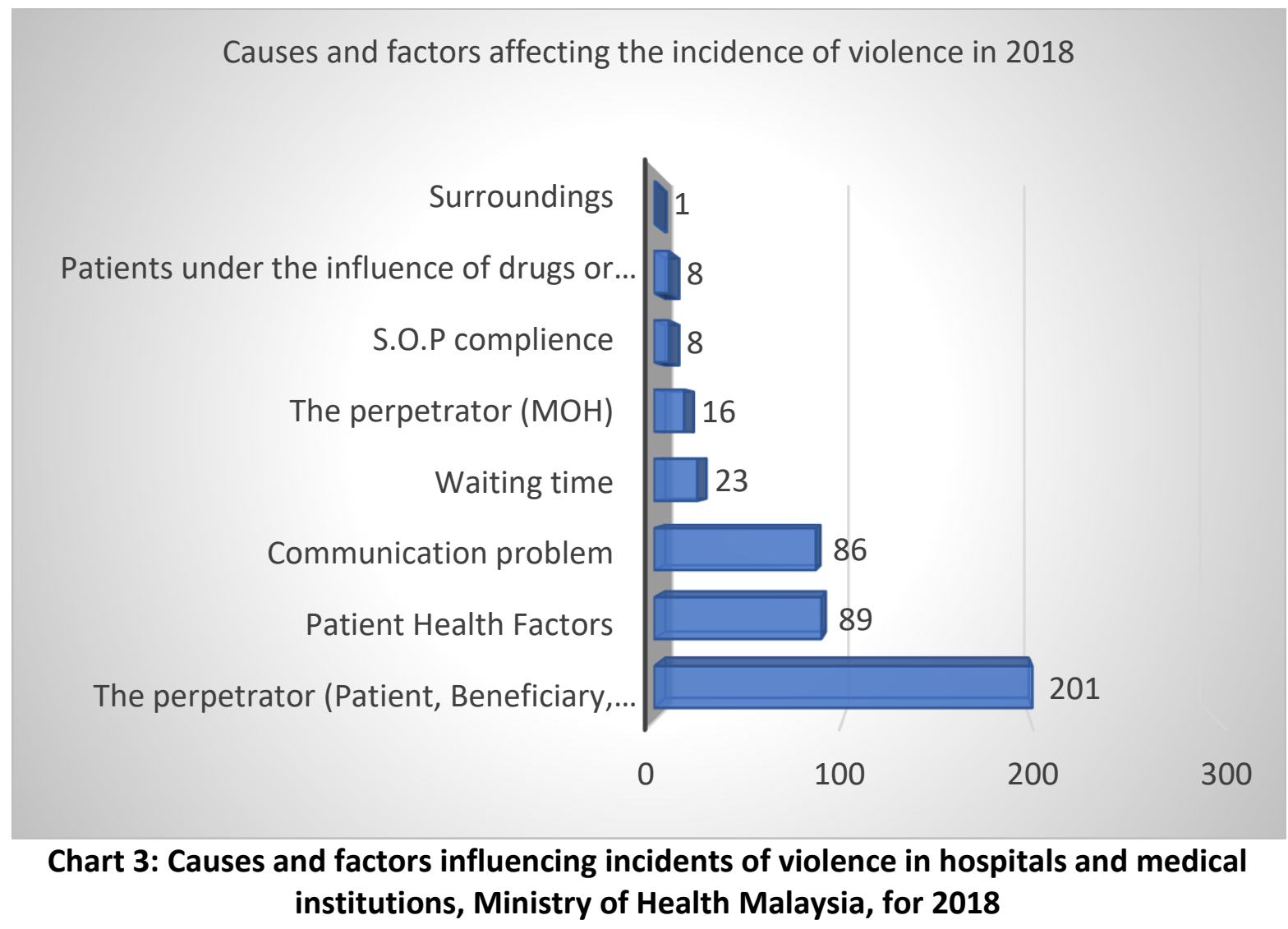

\section{Conclusion}

In essence, due to the frequent occurrence of violent incidents at this health facility, the Ministry of Health Malaysia has taken seriously the actions of individuals who are seen as immoral and unethical. In addition, in compliance with the Guidelines for Preventing and Addressing Violence Against Members at the $\mathrm{MOH}$ Facility and the Ministry of Health Secretary-General's (MOH) Secretary's Letter dated 1 March 2017, the Ministry of Health has issued a prohibition order to make any video recording and images on $\mathrm{MOH}$ facilities such as hospitals and government-click clinics. Any person found to be photographed without permission in a hospital permit is strictly prohibited and legal action may be taken by the authorities in accordance with the Malaysian Penal Code [Act 574] and the Communications and Multimedia Act 1998 with sections and subsections subject to the categories mistakes made. Further, violence against health members whether physical, verbal or written violence including on social media is also an offense and may be subject to legal action

In addition to these scenarios, measures to address the violence against $\mathrm{MOH}$ members were also taken. First, on April 28, 2017, the $\mathrm{MOH}$ launched its Guidelines for Preventing \& Addressing Violence against Members at the $\mathrm{MOH}$ Facility, which helped to raise awareness for $\mathrm{MOH}$ members in the face of workplace violence. Secondly, the $\mathrm{MOH}$ undertook an initiative to produce a Prevention \& Handling Violence Training Module at the MOH Facility on April 27, 2018. The implementation of the module was aimed at providing training of the Training of Trainers (TOT) concept to all members and staff under $\mathrm{MOH}$ facilities. 
Subsequently, the $\mathrm{MOH}$ created the Code Gray. The emergency code created will enable a trained and professional team to handle violent or dangerous incidents to ensure the safety and well-being of health staff and other members. Finally, the $\mathrm{MOH}$ also works with the Royal Malaysian Police to ensure proper investigations and actions are taken against the perpetrators.

\section{Corresponding Author}

Mohammad Fairuszaman Rustam

Faculty of Management and Economics Sultan Idris Education University 35900 Tanjung Malim, Perak, Malaysia

Email: fairuszaman@gmail.com

\section{Reference list}

\section{Journal Articles}

Arnetz, J. E., \& Arnetz, B. B. (2000). Implementation and evaluation of a practical intervention programme for dealing with violence towards health care workers. Journal of Advanced Nursing, 31, 668-680.

Arnetz, J. E., Aranyos, D., Ager, J., \& Upfal, M. J. (2011a). Development and application of a population-based system for workplace violence surveillance in hospitals. American Journal of Industrial Medicine, 54, 925-934.

Arnetz, J. E., Aranyos, D., Ager, J., \& Upfal, M. J. (2011b). Worker on-worker violence among hospital employees. International Journal of Occupational and Environmental Health, 17, 328-335.

Arnetz, J. E., Hamblin, L., Ager, J., Luborsky, M., Upfal, M. J., Russell, J., \& Essenmacher, L. (2015). Underreporting of workplace violence: Comparison of self-report and actual documentation of incidents in hospital settings. Workplace Health and Safety, 63(5), 200-210.

Bride, B. E., Choi, Y. J., Olin, I. W., \& Roman, P. M. (2015). Patient Violence Towards Counselors in Substance Use Disorder Treatment Programs: Prevalence, Predictors, and Responses. Journal of substance abuse treatment, 57, 9-17.

Hamblin, L. E., Essenmacher, L., Upfal, M. J., Russell, J., Luborsky, L., Ager, J., \& Arnetz, J. E. (2015). Catalysts of worker-to-worker violence and incivility in hospitals. Journal of Clinical Nursing, 24, 2458-2467.

Liu, H., Zhao, S., Jiao, M., Wang, J., Peters, D. H., Qiao, H., Zhao, Y., Li, Y., Song, L., Xing, K. (2015). Extent, nature, and risk factors of workplace violence in public tertiary hospitals in china: A cross-sectional survey. International Journal of Environmental Research and Public Health, 12(6), 6801- 6817.

Phillips, J. P. (2016). Workplace violence against health care workers in the United States. New England Journal of Medicine, 374(17), 1661- 1669.

Speroni, K. G., Fitch, T., Dawson, E., Dugan, L., Atherton, M. (2014). Incidence and cost of nurse workplace violence perpetrated by hospital patients or patient visitors. Journal of Emergency Nursing, 40(3), 218-228.

Vellani, K. H. (2014). The 2014 IHSSF crime survey. Journal of Healthcare Protection Management, 30(2), 28-35.

Warren, B. (2011). Workplace violence in hospitals: Safe havens no more. Journal of Healthcare Protection Management, 27, 9-17. 
Zainal, N., Rasdi, I., \& Saliluddin, S. M. (2018) The risk factors of workplace violence among healthcare workers in public hospital. Malaysian Journal of Medicine and Health Sciences, 14 (SP2). pp. 120-127.

\section{Book}

ILO; World Health Organisation. (2002). Framework guidelines for addressing workplace violence in the health sector, International Labour Office: Geneva, Switzerland.

Kementerian Kesihatan Malaysia. (2019). Laporan tahunan KKM 2018. Putrajaya, Malaysia: Cawangan Sumber Maklumat.

Kementerian Kesihatan Malaysia. (2019). Laporan tahunan KKM 2017. Putrajaya, Malaysia: Cawangan Sumber Maklumat.

Kementerian Kesihatan Malaysia. (2017). Garispanduan mencegah dan menangani kekerasan terhadap anggota di fasiliti Kementerian Kesihatan Malaysia.Putrajaya, Malaysia: Unit Keselamatan dan Kesihatan Pekerjaan.

\section{Newspaper Clippings Online}

Che Noh, N. (2017). Petugas kesihatan sering diancam. Berita Harian. https://www.bharian.com.my/node/276872.

Bahaudin, N. H. (2018). JKN Kedah nafi viral ibu mengandung tak dilayan. Berita Harian. https://www.bharian.com.my/berita/kes/2018/04/406060/jkn-kedah nafi-viral ibu mengandung-tak-dilayan. 